\title{
A Case of Choroidal Melanoma Metastatic to the Breast
}

\section{Fallbericht eines malignen Melanoms der Aderhaut mit Brustmetastasierung}

Authors

Affiliations
L. Taran-Munteanu ${ }^{1}$, A. Hartkopf ${ }^{1}$, T. K. Eigentler ${ }^{2}$, U. Vogel $^{3}$, S. Brucker ${ }^{1}$, F. A. Taran ${ }^{1}$

${ }^{1}$ Department of Gynecology, University Women's Clinic Tübingen

2 Department of Dermatology, University Clinic Tübingen

${ }^{3}$ Department of Pathology, University Clinic Tübingen
Key words

- breast metastasis

- choroidal melanoma

- breast-conserving surgery

Schlüsselwörter

- Brustmetastase

- malignes Melanom der Aderhaut

- brusterhaltende Operation received $\quad 2.3 .2016$

revised $\quad 4.4 .2016$

accepted 4.4.2016

\section{Bibliography}

Dol http://dx.doi.org/

10.1055/s-0042-105956

Geburtsh Frauenheilk 2016; 76:

579-581 @ Georg Thieme

Verlag KG Stuttgart · New York . ISSN 0016-5751

\section{Correspondence}

Prof. Dr. med.

\section{Florin-Andrei Taran}

University Women's Clinic

Tübingen

Department of Obstetrics

and Gynecology

Calwerstraße 7

72076 Tübingen

florin-andrei.taran@

med.uni-tuebingen.de

\section{Abstract \\ $\nabla$}

A 61-year-old woman developed blurred vision in her left eye in December 2006. A clinical diagnosis of choroidal melanoma was made. The patient underwent excision of the left lens, followed by vitrectomy and stereotactic radiotherapy. She remained systemically healthy until 50 months later when, during a CT scan done for staging purposes, a newly visible lump was noted in the lower quadrant of her left breast. Core needle biopsy of the lesion in the left breast was performed, and histologic examination revealed metastasis from the choroidal melanoma. The patient underwent breast-conserving surgery of the left breast. Definitive histological examination showed clear tumor margins in the resected specimen and one sentinel lymph node without evidence of metastatic cells. Twenty-nine months after surgery, a similar nodule was detected in the upper quadrant of the left breast. Core biopsy again showed metastatic melanoma, and similar breast-conserving surgery was performed. Systemic examination, including magnetic resonance imaging of the head and computed tomography of the pelvis, abdomen, and chest, was done regularly and revealed no significant findings. Solitary breast metastases from choroidal melanoma are extremely rare. Nevertheless, clinicians should be aware of this rare form of metastasis when treating patients with suspicious breast lesions and a history of choroidal melanoma. If solitary metastasis is confirmed, then breast-conserving surgery may be recommended.

\section{Zusammenfassung \\ $\nabla$}

Im Dezember 2006 entwickelte eine 61-jährige Frau Sehstörungen im linken Auge. Die klinische Diagnose lautet auf malignes Melanom der Aderhaut. Die Patientin unterzog sich einer Vitrektomie, gefolgt von einer stereotaktischen Strahlentherapie. Die Patientin blieb systemisch gesund. Bei einer Nachuntersuchung 50 Monate nach der Erstdiagnose wurde während der Computertomografie ein Knoten im unteren Quadranten der linken Brust entdeckt. Es wurde eine Stanzbiopsie zur Abklärung dieser neuen Läsion durchgeführt. Die histologische Untersuchung ergab, dass es sich hierbei um eine Metastase des malignen Melanoms handelte. Die Patientin unterzog sich einer brusterhaltenden Operation der linken Brust. Bei der definitiven histologischen Untersuchung wiesen die Schnittränder keinen Tumorbefall auf, und die Entfernung eines Wächterlymphknotens brachte keinen Nachweis für metastatische Zellen. 29 Monate nach dieser Operation wurde im oberen Quadranten der linken Brust ein ähnlicher Knoten entdeckt. Die Stanzbiopsie zeigte, dass es sich wieder um ein metastatisches Melanom handelte, und die Patientin unterzog sich erneut einer brusterhaltenden Operation. Es folgte eine regelmäßige Nachkontrolle bestehend aus einer Kernspintomografie des Kopfes und einer Computertomografie des Beckens, Bauches und Brustkorbs. Die Nachkontrollen zeigten keine signifikanten Veränderungen. Einzelmetastasen maligner Melanome der Aderhaut sind äußerst selten. Dennoch müssen Ärzte diese seltene Form der Metastasierung kennen, wenn sie Patientinnen mit verdächtigen Brustläsionen und einer Krankenvorgeschichte von malignem Melanom der Aderhaut behandeln. Sollte sich die Diagnose eine Einzelmetastase bestätigen, wird die Durchführung einer brusterhaltenden Operation empfohlen. 


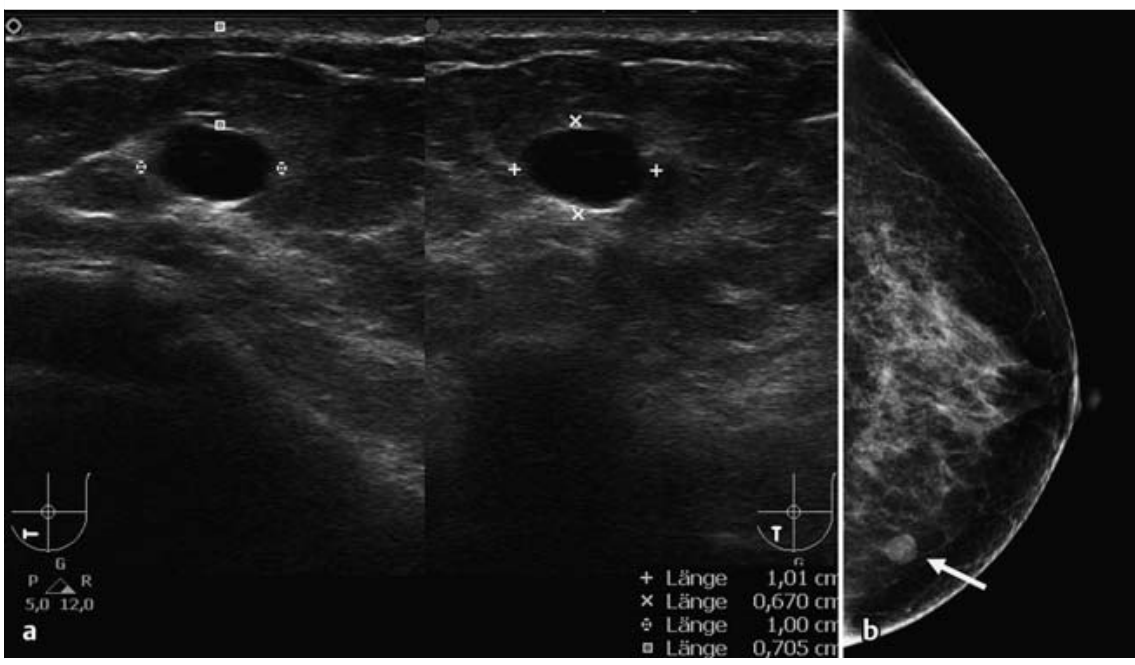

Fig. 1 a and $\mathbf{b}$ Ultrasonography (a) and mammography (b, arrow) of the left breast demonstrated a sharply demarcated, circumscribed lesion measuring 10.1 by $6.7 \mathrm{~mm}$.

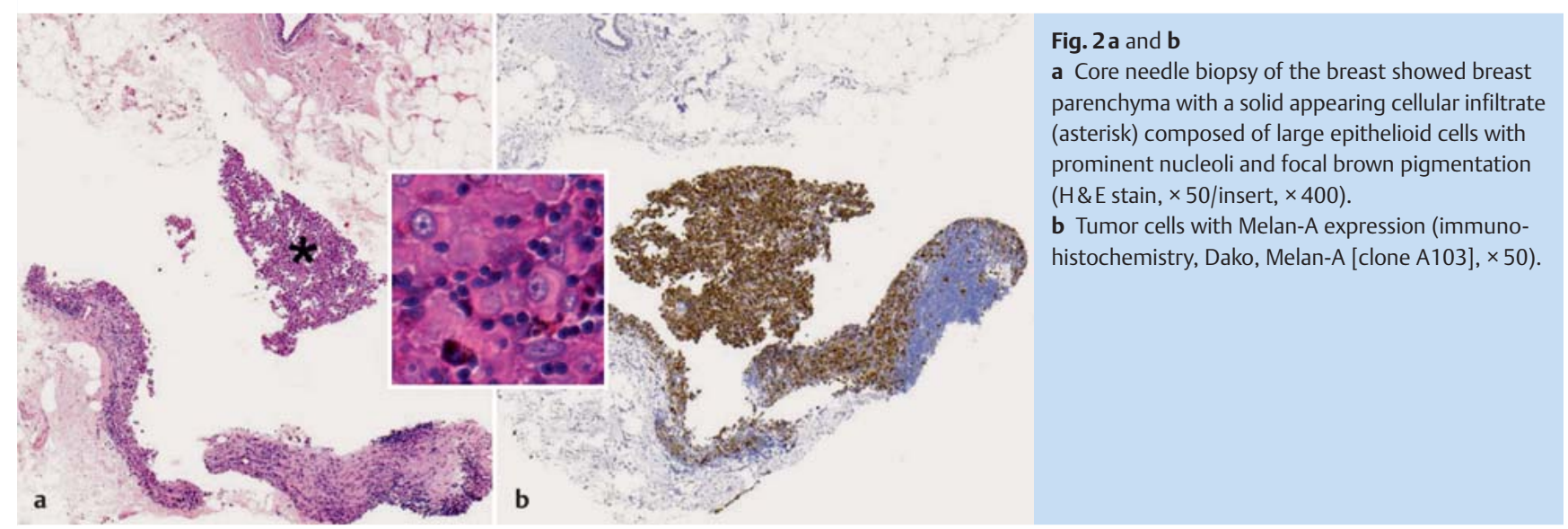

\section{Introduction}

$\nabla$

Uveal melanoma is the most common type of ocular melanoma; the majority of cases occur in the choroid [1]. The incidence of uveal melanoma in Europe was reported to be 2 per million in Spain and Italy, and 4-5 per million in France, the Netherlands, Switzerland, and Germany [1]. The long-term prognosis of metastatic disease is very poor; the most common sites of metastatic disease from choroidal melanoma include the liver, lungs and pleura $[1,2]$.

Invasive breast cancer is the most frequently diagnosed non-dermatologic cancer in women. However, the breast is rarely the site of metastatic disease. We report here on a case with solitary breast metastasis from choroidal melanoma.

\section{Case Report}

\section{$\nabla$}

A 61-year-old woman developed blurred vision in her left eye in December 2006. A clinical diagnosis of choroidal melanoma was made. Apart from an aneurysm of the basilar artery she was in good health. The patient underwent excision of the left lens, followed by vitrectomy and stereotactic radiotherapy with a dose of $25 \mathrm{~Gy}$ in February 2007. She remained systemically healthy until 50 months later when, during a CT scan performed for staging purposes, a newly visible lump was noted in the lower quadrant of her left breast. Ultrasonography ( $\bullet$ Fig. 1 a) and mammography ( Fig. 1 b, arrow) of the left breast demonstrated a sharply demarcated, circumscribed lesion measuring 10.1 by $6.7 \mathrm{~mm}$. The mammogram of the right breast showed unsuspicious calcifications. Core needle biopsy of the breast showed breast parenchyma with a solid appearing cellular infiltrate (asterisk) composed of large epithelioid cells with prominent nucleoli and focal brown pigmentation ( $\$$ Fig. 2 a, H\&E stain, $\times 50$ /insert, $\times 400$ ). Immunohistochemistry revealed tumor cells with Melan-A expression ( Fig. 2b, immunohistochemistry, Dako, Melan-A [clone A103], × 50), confirming the diagnosis of metastasis from the choroidal melanoma. The patient underwent breast-conserving surgery and sentinel node biopsy. Frozen section and definitive histological examination showed clear tumor margins in the resected specimen and one sentinel lymph node without evidence of metastatic cells. Twenty-nine months after treatment, a similar nodule measuring $7 \times 5 \mathrm{~mm}$ was detected in the upper quadrant of the left breast. Core biopsy again showed metastatic melanoma, and similar breast-conserving surgery was performed. Systemic examination, including magnetic resonance imaging of the head and computed tomography of the pelvis, abdomen, and chest, were performed regularly and revealed no significant findings. The interdisciplinary tumor board did not recommend any further therapy. 
Table 1 Course of disease in patients with solitary breast metastasis from choroidal melanoma.

\begin{tabular}{|c|c|c|c|c|c|c|}
\hline Case & $\begin{array}{l}\text { Age } \\
\text { (years) }\end{array}$ & $\begin{array}{l}\text { Time to } 1 \text { st recur- } \\
\text { rence (months) }\end{array}$ & $\begin{array}{l}\text { Time to } 2 \text { nd recur- } \\
\text { rence (months) }\end{array}$ & $\begin{array}{l}\text { Site of } 2 \text { nd } \\
\text { recurrence }\end{array}$ & Therapy & $\begin{array}{l}\text { Follow-up with no evidence } \\
\text { of metastatic disease (months) }\end{array}$ \\
\hline Present case & 61 & 50 & 29 & ipsilateral breast & BCS & 31 \\
\hline Demirci et al. [2] & 48 & 37 & 54 & $\begin{array}{l}\text { contralateral } \\
\text { breast }\end{array}$ & $\mathrm{BCS}$ & 61 \\
\hline $\begin{array}{l}\text { McCormick and Rennie } \\
\text { [6] }\end{array}$ & 50 & 60 & - & - & BCS & 15 \\
\hline
\end{tabular}

$\mathrm{BCS}=$ breast-conserving surgery

Table 2 Summary of findings on breast metastases from non-breast solid malignancies [4].

\begin{tabular}{|l|l|}
$\begin{array}{l}\text { Most common } \\
\text { malignancies }\end{array}$ & Skin melanoma \\
& - Lung cancer \\
\hline Prognosis & Ovarian cancer \\
& Median time of survival from diagnosis: 10 months \\
& of further metastatic disease \\
& Surgical removal could improve survival
\end{tabular}

\section{Discussion}

$\nabla$

While breast cancer is the most common malignancy in women, metastasis to the breast is a rare event and generally occurs as in the setting of advanced systemic disease. The largest studies on metastasis to the breast from non-breast solid malignancies found that metastatic skin melanoma was the most common solid-organ malignancy metastasizing to the breast with an incidence of $38.5 \%$ of all cases, followed by respiratory (lung) and gynecologic (ovarian) malignancies [3,4] ( Table 2).

The majority of uveal melanomas metastasize to the liver, especially if monosomy 3 is present [5]. To our knowledge, this is only the third case of solitary breast metastasis in a female patient from choroidal melanoma reported to date $[2,6]$. The course of disease in our patient and the two previously described cases are summarized in $\bigcirc$ Table 1 . All cases developed metastatic disease more than 36 months after initial diagnosis and were treated with breast-conserving surgery alone $[2,6]$. In one case, solitary metastasis of the contralateral breast occurred 54 months after the first metastatic event and the patient underwent subsequent surgical removal of the lesion [2]. Two of the cases were disease-free at more than 60 months of follow-up.

Chopra et al. reported the first case of breast metastasis from malignant choroidal melanoma in 1972 [7]. The 33-year-old patient presented with rapid enlargement of both breasts caused by metastases from an undetected choroidal melanoma. However, diffuse metastatic disease to the liver and spine was also found in that patient [7]. Esposito et al. reported the only case of breast metastasis from choroidal melanoma in a 72-year-old male patient [8].
Breast metastases from non-breast solid malignancies are generally associated with a poor outcome [4] ( Table 2). The median time of survival from the diagnosis of breast metastasis was reported to be 10 months, with significantly better survival rates reported in patients who had no evidence of further metastatic disease at diagnosis [4]. Furthermore, a significant benefit for survival was noted in patients who underwent surgical removal of breast metastases [4] ( Table 2).

\section{Conclusion}

Solitary breast metastasis from choroidal melanoma is extremely rare. Nevertheless, clinicians should be aware of this rare form of metastasis when treating patients with suspicious breast lesions and a history of choroidal melanoma. If solitary metastasis is confirmed, then breast-conserving surgery may be recommended.

\section{Conflict of Interest \\ $\nabla$}

None.

\section{References}

1 Blum ES, Yang J, Komatsubara KM et al. Clinical management of uveal and conjunctival melanoma. Oncology (Williston Park) 2016; 30: 29$32,34-43,48$

2 Demirci H, Shields CL, Shields JA et al. Bilateral breast metastases from choroidal melanoma. Am J Ophthalmol 2001; 131: 521-523

3 Alva S, Shetty-Alva N. An update of tumor metastasis to the breast data. Arch Surg 1999; 134: 450

4 Williams SA, Ehlers RA 2nd, Hunt KK et al. Metastases to the breast from nonbreast solid neoplasms: presentation and determinants of survival. Cancer 2007; 110: 731-737

5 McCarthy C, Kalirai H, Lake SL et al. Insights into genetic alterations of liver metastases from uveal melanoma. Pigment Cell Melanoma Res 2016; 29: 60-67

6 McCormick A, Rennie I. Bilateral breast metastases from choroidal melanoma. Am J Ophthalmol 2001; 132: 951-952

7 Chopra JS, Chandar K. Bilateral breast metastases from malignant melanoma of the eye. Aust N Z J Surg 1972; 42: 183-185

8 Esposito A, Gentile D, Ghidotti I et al. [A rare case of metastasis of choroidal melanoma in male breast. Mammographic and ultrasonographic diagnosis]. Radiol Med 1994; 88: 487-488 